\title{
Original efficiency indices in PHC patient care
}

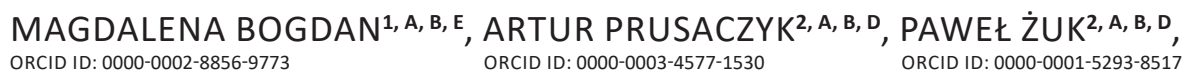 \\ MARIKA GUZEK ${ }^{2, \text { A, B, D }, ~ A N E T A ~ N I T S C H-O S U C H ~}{ }^{1, \text { d, E }}$, JOANNA OBERSKA ${ }^{1, \text { D-F }}$ \\ $\begin{array}{lll}\text { ORCID ID: 0000-0001-5398-9586 ORCID ID: 0000-0002-2622-7348 } & \text { ORCID ID: 0000-0002-6944-4254 }\end{array}$ \\ ${ }^{1}$ Department of Social Medicine and Public Health, Medical University of Warsaw, Poland \\ ${ }^{2}$ Medical and Diagnostic Center in Siedlce, Poland
}

A - Study Design, B - Data Collection, C - Statistical Analysis, D - Data Interpretation, E - Manuscript Preparation, F - Literature Search, G - Funds Collection

Summary Background. The ever-increasing needs and demands of patients, development of new treatments and health services together with limited financial, infrastructural and human resources require an increase in the efficiency of health care while minimizing the cost of this process. Raising cost-effectiveness at the level of individual physicians is a response to the limitations of healthcare resources and high physician involvement in the choice of diagnostics and treatment methods.

Objectives. To develop efficiency indices that can be used in studies on doctors' efficiency in PHC patient care.

Material and methods. The indices were developed following a pilot study at the Medical and Diagnostic Center in Siedlce, Poland, literature analysis and expert consultations. They were based on Data Envelopment Analysis (DEA) methodology and focused on three operational areas: structure, process and outcome. The quality and reliability of the indices were tested on a group of PHC physicians. Results. 11 indices were developed: 1 index within quality of structure (patient population coverage), 7 indices within quality of process (efficiency of working time, efficiency of key appointments, efficiency of comprehensive medical consultations, efficiency of the number of basic and extended check-ups, percentage of pap smear tests, percentage of mammography screening tests, percentage of prophylactic cardiovascular screening tests) and 3 indices within quality of outcome (efficiency of the performance of health care plan, efficiency of the number if issued DILO cards, average years of life).

Conclusions. The proposed indices worked well in practice, and in the future, a collective efficiency scale based on these indices is planned to be developed.

Key words: quality improvement, family practice, primary health care, delivery of health care.

Bogdan M, Prusaczyk A, Żuk P, Guzek M, Nitsch-Osuch A, Oberska J. Original efficiency indices in PHC patient care. Fam Med Prim Care Rev 2021; 23(3): 290-294, doi: https://doi.org/10.5114/fmpcr.2021.108192.

\section{Background}

Limited financial, infrastructural and, above all, human resources, along with the growth of patients' needs and awareness, are the main problems that the health sector in Poland is currently facing [1]. A solution could be increasing the efficiency of health care while minimizing the cost of this process. Raising cost-effectiveness at the level of individual physicians could be a response to tensions related to the limitations of healthcare resources and the ever-increasing demands of patients who use more and more expensive health services. This is because choices regarding particular diagnostic and treatment methods are made by physicians within doctor-patient communication [2].

An increase in the cost-effectiveness of health care requires an increase in the quality of management, the essence of which comes down to productive use of knowledge and the competences of healthcare workers [3]. Competences represent valuable capital that an organization has at its disposal [4]. They can be divided into hard and soft competences [5]. The former refer to knowledge and practical skills. Knowledge can be associated with theories, facts and procedures related to a particular job position or profession. Skills refer to efficiency. Both knowledge and skills are supported by abilities, qualifications and experience [6]. Soft competences refer to behavioral and social aspects [5]. They facilitate the implementation of procedures within the framework of communication with others.

Doctors who are focused on a professional career do not have time to develop both in the field of medicine and man- agement, and therefore they have high medical competences, knowledge and professional skills but often do not have well-developed interpersonal skills. This is why determination of the relationship between the competences of medical workers and the efficiency of patient care in PHC might be of significant importance for the management of medical entities [6]. Appropriate knowledge enables implementation of adequate measures to increase healthcare efficiency and improve the functioning of healthcare entities.

\section{Objectives}

The aim of this article is to present original efficiency indices that can be used in further target studies on doctors' efficiency in PHC patient care. In order to performs the study, 11 indices have been developed that can be used to measure the efficiency of individual doctors.

\section{Material and methods}

The proposed indices are the results of a pilot study conducted at the Medical and Diagnostical Center in Siedlce, Poland, which was conducted by the authors of this paper. The above-mentioned research focuses on the relationship between the competencies of medical staff and the effectiveness of patient care in primary health care. This pilot study allows for the creation and testing original tools (efficiency indices) for mea- 
suring medical staff effectiveness with regard to their reliability and usability for modeling data concerning competencies.

The structure of the distinguished indices was based on practical healthcare managers' (from the MDC company) experiences and sectoral experts' consultations, and it also employed the Data Envelopment Analysis (DEA) methodology.

DEA is based on the assumption made by Charnes, Cooper and Rhodes, who stated that the efficiency of each unit can be presented as a ratio of a weighted sum of outputs over a weighted sum of inputs. Efficiency construed in this way is determined for a specific set of objects called Decision-Making Units (DMU). The DEA method is related to individual persons, and it allows for the measurement of their individual efficiency. Using linear programming, the most efficient object is selected and is marked with the coefficient $100 \%$, whereas the other objects from the examined set are assigned percentages representing the degree of performance of the reference object (benchmark). This object establishes the efficiency threshold, which is also the limit for the set of production possibilities of the analyzed group of objects. This methodology makes it possible to determine the most effective objects in the examined set without the need to determine the functional relationship between inputs and outputs [7]. The research results show that the DEA methodology can support health economic analyses when assessing primary care efficiency [8]. Zakowska and Godycki-Cwirko, in their systematic review concerning data envelopment analysis applications in primary health care, described the most commonly used groups of outputs and inputs and serves as a step towards the standardization of DEA, showing, at the same time, that the most widely used model for efficiency orientation was input orientation [8].

Additionally, quality measurement can be expressed in three areas: structure, process and outcome [9]. Within each area, the characteristics of medical personnel have been distinguished and used to build the indices. They were operationalized so as to enable their presentation as numbers. Each feature was then relativized based on the DEA methodology, as a result of which the final index, characterized by even distribution throughout the entire sample, was created.

The opinion of the Ethics Committee was not needed and was therefore not obtained for the study.

\section{Results}

The research sample consists of 65 PHC doctors employed with the Medical and Diagnostic Center in Siedlce (MDC). Finally, after excludion due to the lack of data or lack of possibility to assess their effectiveness, 29 respondents were included in the process of purposive sampling. Purposive sampling involves selection of only those participants whose data can be regarded as useful for the feasibility of the study. Purposive sampling was performed correctly, as the final study sample (29 PHC doctors) included PHC doctors who cared for $94 \%$ of the MDC patient population (in total around 90,000 patients).

\section{Efficiency in health care}

An analysis of the research on efficiency in health care and the influencing factors shows that the studies conducted in Poland so far have focused on the efficiency of entire medical entities, or even healthcare systems, rather than individuals. At the same time, the aim of the research, focused on individuals (physicians), was to identify factors influencing patient satisfaction and not the efficiency of care.

To ensure high quality of care, it is important to assess if patient needs are being met. A survey evaluation performed by Marcinowicz et al. in the north-eastern part of Poland showed that although most of the respondents indicated that patients should evaluate the quality of provided care, a significantly lower amount declared participation in such assessments [10]. This definitely shows the need to create objective, data-driven indices which would measure the quality of care without directly involving patients while still focusing on meeting their needs.

Determination of the relationship between the efficiency of care and social competences requires a focus on individuals, i.e. physicians. This approach is possible, and it has theoretical foundations: as indicated by Bober and Olkiewicz, the overall efficiency of public entities is the sum of the efficiency measures of individual diagnostic and therapeutic positions in the entities [11]. Therefore, it is possible to determine the relationship between the competences of medical personnel and the efficiency of individual workers.

In order to perform a study on efficiency, it is necessary to properly define the notion of efficiency. This can be viewed from the perspective of performance and cost-effectiveness. The former comes down to financing medical services that guarantee the maximum state health of the population at the given costs. Its improvement involves increasing the number of medical services using particular finances. The latter involves offering medical services that guarantee a particular state of health of the population at minimum costs. The aim is therefore to improve the effectiveness of treatment at particular costs [12]. Both healthcare value and efficiency increase along with an increase in the quality of care or a decrease in the cost of care.

Suchecka and Owczarek analyzed the definitions of the efficiency of medical services in American organizations and defined it as "an attribute of the healthcare model measured as the relationship between the healthcare system product (output) and the expenditures necessary to create this product (input)". Importantly, following this definition, a service provider can be both a medical entity and an individual doctor [13]. Palmer and Togerson presented a more operational dimension of this concept. In their opinion, efficiency is the relationship between the inputs (labor, capital and equipment costs) and the intermediate or final outputs. Intermediate outputs are factors such as the number of recovered patients or the waiting time for a particular health procedure. The final outputs include the number of patients saved from death, extended life years or time free from symptoms of disease [14]. This definition opens up the scope for the selection of efficiency indicators. For the purpose of the study presented in this paper, efficiency has been defined as the relationship between inputs and intermediate outputs, as these can be related to particular physicians, while the final outputs can be related to the entire medical entity.

\section{Original efficiency indices in PHC patient care}

Assuming that efficiency is the relationship between inputs and intermediate outputs, the simplest possible method of measuring this is by using the performance index. In the United States, it is used for internal evaluation of the efficiency of physicians who are remunerated for their performance. The output translates into the total number of patients, whereas the input is the number of hours spent by the physician caring for patients [13]. The performance index does not take into consideration the cost of treatment, and neither does it assess the appropriateness of treatment. In order to include the aspect of doctors' labor costs in the concept of efficiency, indicators used for measuring efficiency in health care were analyzed. Some of these were used to transfer the concept from the level of medical entities and entire health systems to the level of individual doctors.

The quality of the structure is measured using hard and soft factors, which constitute the resources of a medical facility. These include the number, education and experience of medical staff; medical equipment; infrastructure; organizational structure; organizational culture; management styles. These factors are useful for the presentation of the quality of functioning of the entire entity and the operational context of medical personnel. In this study, all factors are common to all respondents, and 
they have no impact on the results; however, they make it possible to explain the observed phenomena. The exceptions are the individual characteristics of the staff, such as their education and experience, which build the first group of analyzed variables.

\section{Patient population coverage}

The index value is calculated as the average number of patient registration forms per particular doctor in a given year, divided by the average number of patient registration forms in the entity in a given year. If a study involves multiple entities, it is necessary to sum up the registration forms from all entities. The higher the patient's satisfaction, the higher the number of registration forms should be to prove that high quality of care is provided by a given physician.

The quality of the process is both a purely technical dimension, including diagnosis and treatment, and a communicative dimension, including effective communication, which makes it possible to obtain the necessary data and give recommendations to patients. The technical dimension of care is related to the applied procedures and individual characteristics of the medical staff. Assessment of the quality of care also involves effective communication between medical workers and patients.

\section{Efficiency of working time}

The value of the index is calculated as the value of the physician's annual base salary, divided by the total real working time of the physician in the given year. The choice of the salary factor results from the desire to obtain the cumulative financial value of the doctor's man-hour, i.e. efficiency.

\section{Efficiency of key appointments}

The value of the index is calculated as the value of remuneration for key appointments (house visits and follow-up visits) per particular physician in a given year, divided by the total real working time of the physician per year. The index is intended to illustrate the efficiency of the doctor's visits. The weighting of different types of medical visits is based on the desire to consider different weights and levels of difficulty of visits. The value of remuneration at the Medical and Diagnostic Center in Siedlce (CMD) is based on economic reasoning and appropriate differentiating means.

\section{Efficiency of comprehensive medical consultations}

The value of the index is calculated as the total value of remuneration for comprehensive and follow-up medical consultations per particular physician in a given year, divided by the total real working time of the physician per year. The weighting of individual types of services is based on the value of remuneration per service, which allows for proper measurement of the weight and difficulty of the service.

Efficiency of the number of comprehensive medical consultations

The index value is calculated as the number of comprehensive and follow-up medical consultations per particular physician per year, divided by the total real working time per physician per year. This is a control index in relation to the previous. It allows for the determination of the impact of the number of consultations on efficiency alone, without taking into consideration the weight and difficulty of a consultation.

Efficiency of the number of basic and extended check-ups

The value of the index is calculated as the number of basic and extended check-ups per particular physician per year, divided by the total real working time per physician per year. The index is intended to illustrate the efficiency of the physician's work expressed in the number of check-ups made.

\section{Percentage of pap smear tests}

The index value is calculated as the number of patients who had a pap smear test per particular physician per year, divided by the total number of patients per physician. It is assumed that the percentage of patients who require the test per doctor should be similar. The performance of a pap smear test should therefore confirm the doctor's efficiency in referring patients to prophylactic tests and their efficiency in communication with patients.

\section{Percentage of mammography screening tests}

The index value is calculated as the number of patients who had a mammography screening test per particular physician per year, divided by the total number of patients per physician. As in the case of the percentage of pap smear screening tests, the index should present the doctor's efficiency in referring patients to prophylactic tests and their efficiency in communication with patients.

Percentage of prophylactic cardiovascular screening tests

The index value is calculated as the number of patients who had prophylactic cardiovascular screening tests per particular physician per year, divided by the total number of patients per physician. As in the case of the percentage of pap smear tests and mammography screening tests, the index should present the doctor's efficiency in referring patients to prophylactic tests and their efficiency in communication with patients.

The quality of the outcome is measured using healthcare efficiency indicators: mortality, morbidity, complications, side effects and patient satisfaction. In order to assess the work of individual physicians, the concept of self-efficacy can be used. This is one of basic beliefs, on the basis of which all other human beliefs are shaped. Self-efficacy correlates with high self-esteem, self-acceptance and an optimistic attitude. It also creates expectations towards the undertaken activities [15]. A sense of self-efficacy understood in this way was operationalized and used in a study by Hulewska, which was conducted in order to determine the correlation between physicians' assertiveness (interestingly defined as empathy) and the sense of self-efficacy, job satisfaction and stress [16].

\section{Efficiency of the performance of the healthcare plan}

The index value is calculated as the number of patients of a given physician who actively implement their healthcare plan (patients who have received an individual plan of medical care (IPOM) and had a comprehensive medical visit in the given year), divided by the average number of patients registered by a given physician as chronically ill during the year. The index is used to present the effectiveness of a given doctor in persuading patients to actively implement their healthcare plan. A high index value is supposed to confirm the high communication skills of the doctor and their positive influence on patients.

Efficiency of the number of issued oncology diagnosis and treatment cards (DILO)

The index value is calculated as the number of DILO cards issued by a given doctor during the year, divided by the average number of their patients in the year. The percentage of patients with cancer should be similar among patients of different doctors. A higher percentage of diagnosed cancer cases indicates the high efficiency of a given doctor. Although it is worth comparing the number of issued DILO cards with the number of actually detected cancer cases, this is not possible due to the lack of data, and hence the necessity to rely only on the number of issued DILO cards.

\section{Average years of life}

The index value is calculated as the average years of life of deceased patients per particular doctor in a given year. The value of the index presents the overall, collective efficiency of a given doctor in providing care for their patients.

Therefore, it should be added that the average years of life indicator depends on numerous factors. Many of them have 
a stronger impact on the average years of life than the primary healthcare subsystem. The average years of life index could be more related to the effectiveness of the entire healthcare system rather than just physicians working in primary health care. This inconsistency causes a necessity for further verification of the scope and impact of the above-mentioned index in the research on a wider sample.

\section{Discussion}

The efficiency indices presented in this article were developed on the basis of a literature review, expert consultations and a pilot study that had been performed at the Medical and Diagnostic Center in Siedlce. The only participants in the study were PHC doctors, which made it possible to assess the reliability of the tools. However, the small size of the sample prevented a search for relationships between the variables and the isolation of measurement scales reliable for the efficiency of patient care.

The efficiency indices proved to work well in practice. First of all, it can be observed that the values of individual indices are relatively evenly distributed, which mainly results from value relativization using the DEA methodology. The distribution of the result values made it possible to capture differences in the efficiency of doctors and compare the level of efficiency with the level of social competences. An exception is the patient's life expectancy index. Although it seems to be very important for the assessment of the efficiency of doctors, small differences between the values of the results made it difficult to observe the discrepancies between the results. In further studies on a larger sample, it will be important to develop the index in a way that will allow for greater diversification of the results.

As a result of the pilot study, two efficiency indices were abandoned. In the case of "life expectancy of chronically ill patients", the distribution was almost identical to that of all patients. The "creative destruction" index showed high sensitivity to the number of patients of a given doctor (newly employed doctors obtained very high index values).

The indices proposed in this study are in line with the findings of a recent systematic review of primary health care quality indicators. Among the 727 indicators analyzed in the study, there were e.g. management and control of chronic conditions, treatment choice, preventable hospitalizations, development of screening programs, utilization of screening tests, effectiveness and efficiency of care, waiting time to treatment and consultation [17]. Szwamel and Kurpas have argued that the number of emergency department (ED) visits could also be an important indicator of the quality of provided primary health care. By meeting the needs of patients, PHC physicians are playing the role of gatekeepers to the healthcare system. The authors noticed that among the most frequently performed treatments, a majority of them were not rescue procedures and could be performed in the outpatient clinic [18]. This notion is supported by a 2012 systematic review which identified that interventions effective in reducing ED use increase primary care accessibility and ED cost-sharing [19].

In the perspective of wider research, further incorporation and comparative analysis of two European Commission founded projects might be valuable. The first is the QUALICOPC (Quality and Costs of Primary Care in Europe) study, which aims to analyze and compare how the primary healthcare systems in 34 countries perform in terms of quality, costs and equity [20]. The second, the Primary Health Care Activity Monitor for Europe, concentrated on the lack of up-to-date comprehensive and comparable information on variations in development of primary care and the lack of knowledge of structures and strategies conducive to strengthening primary care in Europe. The PHAMEU project aims to fill this gap by developing a Primary Care Monitoring System (PC Monitor) for application in 31 European countries [21]

\section{Limitations of the study}

The main limitation of the study is the limited scope of researched subjects - only one medical unit. Analyzing only one medical unit is characteristic for the pilot study methodology. At this preliminary stage, we have only concentrated on creating and testing the concepts of original tools (efficiency indices) for measuring medical staff effectiveness. However, in the following stages, an increased number of medical unites should be included and analyzed in order to obtain and test the variations of efficiency indices.

\section{Conclusions}

Although there are some limitations to the study, the proposed original indices worked well in practice and can be used in further studies on doctors' efficiency in PHC patient care.

A promising solution for the future seems to be the development of a collective efficiency scale based on the already applied efficiency indices. As part of the pilot study, a scale consisting of six indexes was created, four of which were related to the measurement of the quality of work in CMD (efficiency of key appointments, efficiency of comprehensive medical consultations, efficiency of the number of comprehensive medical consultations, efficiency of basic and extended health check-ups) and the remaining two general indices were interrelated strongly enough to become a single scale (coverage of the patient population, average years of life).

Source of funding: This work was funded from the authors' own resources.

Conflicts of interest: The authors declare no conflicts of interest.

\section{References}

1. Departament Zdrowia Najwyższej Izby Kontroli. Raport: system ochrony zdrowia w Polsce - stan obecny i pożq̨ane kierunki zmian. Warszawa: NIK; 2019. Available from URL: https://www.nik.gov.pl/plik/id,20223,vp,22913.pdf (in Polish).

2. Ginsburg ME, Kravitz RL, Sandberg WA. A survey of physician attitudes and practices concerning cost-effectiveness in patient care. West J Med 2000; 173(6): 390-394.

3. Walczak W. Przywództwo i motywowanie w procesach zarządzania kompetencjami pracowników. E-mentor 2011; 1: 38. Available from URL: http://www.e-mentor.edu.pl/artykul/index/numer/38/id/808 (in Polish).

4. Karnej P, Łyś D, Grzebieluch J. Wpływ kompetencji pracowników medycznych na funkcjonowanie praktyki lekarza rodzinnego. Fam Med Prim Care Rev 2012; 14(1): 24-28 (in Polish).

5. Armstrong M. Zarzqdzanie zasobami ludzkimi. Kraków: Oficyna Ekonomiczna, Dom Wydawniczy ABC; 2005 (in Polish)

6. Kęsy M. Kształtowanie kompetencji menedżerskich personelu medycznego w szpitalach. Kraków: Wydawnictwo UJ; 2013 (in Polish).

7. Bartoszewicz A, Lelusz H. Idea i kierunki wykorzystania metody DEA do pomiaru efektywności działania gmin - wybrane aspekty. Finanse, Rynki Finansowe, Ubezpieczenia 2016; 80: 217-225 (in Polish).

8. Zakowska I, Godycki-Cwirko M. Data envelopment analysis applications in primary health care: a systematic review. Fam Pract 2020; 37(2): 147-153. 
9. Czerw A, Religioni U, Olejniczak D. Metody pomiaru oraz oceny jakości świadczonych usług w podmiotach leczniczych. Probl Hig Epidemiol 2012; 93: 269-273 (in Polish).

10. Marcinowicz L, Gugnowski Z, Strumiło J, et al. Do patients want to evaluate the quality of health care? A short survey among patients. Fam Med Prim Care Rev 2015; 17(1): 28-32.

11. Bober B, Olkiewicz M. Jakościowe czynniki efektywności procesu świadczenia usług szpitalnych. Zeszyty Naukowe Uniwersytetu Przyrodniczo-Humanistycznego w Siedlcach, Seria: Administracja i Zarzqdzanie 2013; 25(98): 269-278 (in Polish).

12. Krot E. Efektywność w służbie zdrowia widziana przez pryzmat jakości. Rocznik Kolegium Analiz Ekonomicznych 2012; 25: 103-115 (in Polish).

13. Suchecka J, Owczarek K. Mierniki efektywność usług medycznych w amerykańskim systemie opieki zdrowotnej. Probl Zarzq̨dz 2011; 9 , 3(33): 79-92 (in Polish).

14. Palmer S, Torgerson DJ. Definitions of efficiency. BMJ Clin Res 1999; 318(7191): 1136.

15. Bandura A. Self-efficacy: toward a unifying theory of behavioral change. Psychol Rev 1977; 84(2): 191-215.

16. Hulewska A. Asertywność a stres, poczucie własnej skuteczności i satysfakcja z pracy doświadczane przez lekarzy. Zesz Prasozn 2015; 58, 2(222): 276-283 (in Polish).

17. Ramalho A, Castro P, Gonçalves-Pinho M, et al. Primary health care quality indicators: an umbrella review. PLoS ONE 2019; 14(8): e0220888.

18. Szwamel K, Kurpas D. Assessment of the health care system functioning in Poland in light of the analysis of the indicators of the hospital emergency department (ED) and primary health care (PHC) - proposals for systemic solutions. Fam Med Prim Care Rev 2019; 21(2): 164-173.

19. Flores-Mateo G, Violan-Fors C, Carrillo-Santisteve P, et al. Effectiveness of organizational interventions to reduce emergency department utilization: a systematic review. PLOS ONE 2012; 7(5): e35903.

20. Quality and Costs of Primary Care in Europe (QUALICOPC) [cited 31.05.2021]. Available from URL: https://www.nivel.nl/en/international-projects/qualicopc.

21. Primary Health Care Activity Monitor for Europe (PHAMEU) [cited 31.05.2021]. Available from URL: https://www.nivel.nl/en/project/ phameu-primary-health-care-activity-monitor-europe.

Tables: 0

Figures: 0

References: 21

Received: 07.03.2021

Reviewed: 15.03.2021

Accepted: 13.06 .2021

Address for correspondence:

Joanna Oberska, BSc

Zakład Medycyny Społecznej i Zdrowia Publicznego

Warszawski Uniwersytet Medyczny

ul. Oczki 3

02-007 Warszawa

Poland

Tel.: +48 506376998

E-mail: joannaoberskaa@gmail.com 